\title{
Cash Holdings and Excess Credit-Empirical Evidence from Chinese Listed Companies
}

\author{
Ming Bai ${ }^{1, a}$ and Zhongzheng Qiao ${ }^{1, b^{*}}$ \\ ${ }^{1}$ School of Economics and Management, Beijing University of Aeronautics and Astronautics, Beijing, \\ 100191, China; \\ abaimingbm@buaa.edu.cn, 'piaozhongzheng@buaa.edu.cn, ${ }^{*}$ Corresponding author
}

Keywords: cash holdings, excess credit, Probit model.

\begin{abstract}
This paper studies the impacts of cash holdings on excess credit using a balanced panel of 988 Chinese listed companies. Regression results show negative correlation between cash holdings and the possibility of occurrence of excess credit in Probit model. The lower the corporate cash holdings level, the higher the probability that the enterprise appears excess credit. Empirical results are consistent with the pecking order theory, corporate cash holdings policy can affect the corporate financing decision.
\end{abstract}

\section{Introduction}

In 2008, in reaction to the global financial crisis, Chinese government put forward the "four trillion RMB" stimulating domestic demand plan, implemented a loose monetary policy at the same time. At the end of 2014, People's Bank of China cut the benchmark interest rate and the deposit reserve rate many times, in order to increase money supply and expand enterprise investment. At present, the investment of Chinese enterprises overall is overheating, which is associated with the excess credit phenomenon. For a long time, there is a widespread excess credit situation of Chinese enterprises, especially the country's economic policy allows banks to increase credit, making the majority enterprise actual loan is higher than the loan they need.

Cash as a universal equivalent is widespread in the field of social production and circulation; it is an indispensable resource of the company's daily operations and management activities. Corporate cash holdings are closely related to their various activities such as investment, financing and dividend payments. Listed companies in order to meet the needs of growth and investment, without financing, they choose to hold a certain amount of cash. Cash holdings is a very important problem of modern corporate governance theory and practice, excess credit phenomenon accompanied with the development of Chinese economy and the formulation and implementation of Chinese economic policy, has been little studied by academics and the research about how cash holdings effects the excess credit is still a gap.

\section{Theory analysis}

Capital structure is an important academic field which is studied widely by Chinese and foreign scholars, it is affected by many factors, including company size, profitability, growth capacity, etc ${ }^{[1-3]}$. Rajan and Zingales regarded that the company's size and debt level is positive correlated, they think the companies can use their massive assets as collateral, so borrow more money at relatively low cost, thus they can get more debt financing ${ }^{[4]}$. In addition, the growth of debt is a signal of investment, companies have growth opportunities will get more debt, rather than only through internal financing.

But the existing research rarely involves the impact of cash holdings on the capital structure, the previous study found that when the level of corporate cash holdings increased the leverage levels declined ${ }^{[5,6]}$. The conclusion is consistent with the theory of financing constraints, these debt capital can be considered to be instead of other funds, when the level of corporate cash holdings is high, it will use the adequate funds for investment projects, the need for external debt financing will be reduced, so enterprise's debt level is low ${ }^{[7]}$. 
In the pecking order theory, widespread asymmetric information is existed in social and economic life, which will inevitably lead to a variety of intangible costs, in order to minimize the cost of information asymmetry and the cost of financing, corporate financing will exist a certain order. In general, corporate financing prefers internal financing and then external financing, the financing order is retained earnings, debt financing, and equity financing. It can be explained that when the cash flow generated by the company's operating activities can meet the requirements of companies' investment, the company will choose to repay the debt before, or choose to accumulate funds. When the retained earnings are less than the capital which investment required, companies will use the cash previously accumulated or issue bonds according to the funding gap. That is to say, when the company's cash holdings level is high, the company will reduce the credit financing, at the same time it has the ability to repay the debt, so the possibility of excess credit declines; and when the company has cash shortage and internal financing cannot meet the requirement, it is necessary to increase the enterprise credit, so the probability of excess credit increases. Statistically, corporate cash holdings is negative correlation with excess credit.

\section{Data and model}

\subsection{Data}

The sample is selected from the A shares listed companies in Shanghai and Shenzhen from 2004 to 2014, the data is from wind database. This paper follows the following principles to filter samples: (1)the environment of financial and insurance industry are different from other industries, thus eliminate such listed companies; (2) the companies which listing and delisting or had been ST from 2004 to 2014 are eliminated; (3) exclude the abnormal sample data which the Debt-to-assets ratio is greater than 1; (4) remove the sample that company data disclosed incomplete. After screening we got a balance panel data of 988 listed companies over 11 years.

\subsection{Variables selection and measurement}

At present, there are two main modes about the excess credit measurement: the first mode, estimate corporate normal leverage ratio based on financial characteristics and governance structure, then calculate the difference between enterprise actual leverage and estimated leverage, the result is the proxy variables about excess credit and credit deficiency ; the second mode, regard the industry average leverage as a benchmark, companies higher than the industry average are excess credit.

Based on the mode 1, we select explanatory variables refer to Maosheng R.'s research ${ }^{[8,9]}$, the model to measure corporate normal leverage is as follows(model 1) . LEV is corporate leverage ratio; CASH is corporate cash holdings level, calculated by (monetary capital + tradable financial assets)/total assets; SIZE is the logarithm of corporate total assets; ROE is corporate after-tax profit/owner's equity; GROWTH is the growth rate of business income; TOP1 is the proportion of corporate first largest shareholder; LIQUID is corporate net value of fixed assets divided by total assets; PROFIT is corporate EBIT divided by total assets; $\mathrm{Z}$ is corporate debt paying ability, it is total market value divided by total liabilities.

We use mixed panel data model and Least squares estimation to estimate the equation, the residuals reflect the degree of excess credit / credit deficiency. When the company's actual leverage ratio > estimated average ratio, OVERLEV $=1$, said the enterprise excess credit; the actual leverage ratio < the estimated leverage ratio, OVERLEV $=0$, said the enterprise credit deficiency.

\subsection{Model specification}

We take the probability of occurrence of excess credit as the explained variable, which itself is a dual qualitative variable, namely when the enterprise has excess credit, defined as 1 ; when the enterprise doesn't have excess credit, defined as 0 . There are two models for us to choice, Probit model and Logit model, considering some of the control variables are assignment for 0 , it is not suitable for the application of Logit model, so this study adopts the estimation method of Probit model.

We select control variables of excess credit model refer to the research ofand Wenzhou L. ${ }^{[9]}$ and Locan T. R.etc. ${ }^{[10]}$, including firm size(SIZE), return on invested capital(ROIC), growth rate of operating activities net cash flows(EB), net capital expenditure(CAPEX), corporate financial 
expenses(FE), stock liquidity (LIQ,LIQ=stock market value/stock trading volume)and the nature of enterprise (NATURE; state owned enterprises NATURE $=0$, non state owned enterprises NATURE=1).In order to contrast the regression results of Probit model, we establish multiple linear regression model (model 2).

\section{Results}

\subsection{Descriptive Statistics}

Table 1 is the basic descriptive statistics for the variables. Table 2 is the correlation coefficient matrix of these variables.

Table 1 descriptive statistics of variables

\begin{tabular}{|c|c|c|c|c|c|c|c|c|c|}
\hline variables & & mean & \multicolumn{2}{|l|}{ median } & \multicolumn{2}{|l|}{ maximum } & minimum & \multicolumn{2}{|c|}{ standard deviation } \\
\hline OVERLEV & & 0.5133 & \multicolumn{2}{|l|}{1} & \multicolumn{2}{|l|}{1} & 0.0000 & \multicolumn{2}{|l|}{0.4998} \\
\hline CASH & & 0.1581 & \multicolumn{2}{|l|}{0.1310} & \multicolumn{2}{|l|}{0.9309} & 0.0005 & \multicolumn{2}{|l|}{0.1142} \\
\hline SIZE & & 21.9196 & \multicolumn{2}{|l|}{21.8054} & \multicolumn{2}{|l|}{28.0035} & 17.5367 & \multicolumn{2}{|l|}{1.2647} \\
\hline ROIC & & 0.0476 & \multicolumn{2}{|l|}{0.0397} & \multicolumn{2}{|l|}{1.0263} & -1.0523 & \multicolumn{2}{|l|}{0.0856} \\
\hline EB & & 1.1220 & \multicolumn{2}{|l|}{0.0884} & \multicolumn{2}{|l|}{978.3420} & -1239.2440 & \multicolumn{2}{|l|}{29.9512} \\
\hline FE & & -0.1137 & \multicolumn{2}{|l|}{0.1118} & \multicolumn{2}{|l|}{755.7328} & -2884.2980 & \multicolumn{2}{|l|}{30.2525} \\
\hline CAPEX & & 0.0537 & \multicolumn{2}{|l|}{0.0374} & \multicolumn{2}{|l|}{0.5453} & 0.0000 & \multicolumn{2}{|l|}{0.0546} \\
\hline LIQ & & 32.6410 & 2.8789 & & 222080.10 & & 0.0000 & 2234.74 & \\
\hline STÄTE & & 0.3836 & 0.0000 & & 1 & & 0.0000 & 0.4863 & \\
\hline & & Table $2 \mathrm{Pe}$ & rson correl & ation coe & fficient I & atrix 0 & f variables & & \\
\hline OVERLEV & $\begin{array}{l}\text { OVERLEV } \\
1\end{array}$ & $\mathrm{CASH}$ & SIZE & ROIC & EB & $\mathrm{FE}$ & CAPEX & LIQ & NATURE \\
\hline CASH & $-0.0672 * * *$ & 1 & & & & & & & \\
\hline SIZE & $0.0614 * * *$ & $-0.0788 * * *$ & 1 & & & & & & \\
\hline ROIC & $-0.1372 * * *$ & $0.2626 * * *$ & $0.1566 * * *$ & 1 & & & & & \\
\hline EB & -0.0006 & 0.0112 & -0.0090 & $0.0228 * *$ & 1 & & & & \\
\hline FE & 0.0072 & -0.0006 & 0.0055 & 0.0098 & 0.0004 & 1 & & & \\
\hline CAPEX & $0.0407 * * *$ & $-0.1050 * * *$ & $0.1299 * * *$ & $0.1172 * * *$ & 0.0092 & -0.0006 & 1 & & \\
\hline LIQ & -0.097 & -0.0019 & -0.0087 & -0.0019 & -0.0004 & 0.0001 & -0.0038 & 1 & \\
\hline NATURE & 0.0020 & $0.0294 * * *$ & $-0.2274 * *$ & -0.0110 & 0.0065 & 0.0097 & $-0.0658 * * *$ & $-0.0074 * * *$ & 1 \\
\hline
\end{tabular}

Note: $* * *, * *$ and $*$ denote statistical significance at the $0.01,0.05$, and 0.10 level, respectively.

From the descriptive statistics of variables (Table 1), it can be seen that the companies median excess credit is1, the mean is 0.5133 , which means more than half of the sample firms have excess credit. From the variables' Pearson correlation coefficient matrix (Table 2) we can see that no obvious correlation exist between the control variables, the highest is the cash holdings(CASH) and return on invested capital(ROIC), the correlation coefficient is 0.2626. The other coefficients between variables are relatively small.

Through further observation, it can be found that the cash holdings variable is negatively correlated with the excess credit, which is consistent with our previous analysis and provides preliminary support for our study.

\subsection{Cash holdings and excess credit}

Table 3 is the empirical results of the impact of cash holdings on the company's excess credit, the first column is the test result of Probit model, the second column is a reference which based on multiple linear regression (model 2). It can be seen that in both Probit model and multiple linear regression model, the coefficient of cash holdings is significantly negative, which means cash holdings and excess credit are negatively correlated in Chinese listed companies. That is the lower corporate cash holdings level, the more prone to excess credit, whereas the level of corporate cash holdings is higher, the lower the probability of excess credit. So we can see that as an important variables of corporate governance the company's cash holdings also affect the enterprise's financing decisions, when the level of cash holdings is low, enterprises will expand their debt financing, so as to avoid the pressure of debt and the loss of high quality investment opportunities; and when the level of corporate cash holdings is higher, the demand of corporate borrowing is also decreased, enterprise's own funds can meet the investment, enterprise will give preference to internal financing, which is consistent with the pecking order theory, at the same time the high level of cash holdings 
also makes the enterprises have the ability to repay debt, which makes the enterprises' debt levels are low, the probability of excess credit is reduced.

Table 3 the regression results of cash holdings and excess credit

\begin{tabular}{lll}
\hline variables & Probit model & multiple linear regression model \\
\hline CASH $_{\mathrm{t}}$ & $-0.329^{* * *}$ & $-0.090^{* *}$ \\
$\mathrm{SIZE}_{\mathrm{t}}$ & $(-2.864)$ & $(-1.993)$ \\
& $0.006^{* * *}$ & $(49.943)$ \\
ROIC $_{\mathrm{t}}$ & $(4.665)$ & $-0.863^{* * *}$ \\
$\mathrm{~EB}_{\mathrm{t}}$ & $-2.126^{* * *}$ & $(-14.194)$ \\
& $(-13.046)$ & 0.0001 \\
$\mathrm{CAPEX}_{\mathrm{t}}$ & 0.0001 & $(0.298)$ \\
& $(0.292)$ & $0.437^{* * *}$ \\
$\mathrm{FE}_{\mathrm{t}}$ & $1.154^{* * *}$ & $(4.710)$ \\
& $(4.819)$ & 0.0001 \\
LIQ $_{\mathrm{t}}$ & 0.0004 & $(0.825)$ \\
& $(0.790)$ & -0.0001 \\
NATURE & -0.0001 & $(-0.925)$ \\
& $(-0.704)$ & $0.018^{*}$ \\
Total obs & 0.006 & $(1.753)$ \\
Log likelihood & $(0.247)$ & \\
Avg.log likelihood & 9880 & \\
Observation & -6724.957 & 9880 \\
R-squared & -0.681 & 0.029 \\
adj. R-squared & & 0.028 \\
\hline
\end{tabular}

Note: the figures in parentheses in the Probit model are $\mathrm{Z}$ test values, and the figures in parentheses in the multiple linear regression model are $\mathrm{t}$ test values. ${ }^{* * *}$, ${ }^{* *}$ and $*$ denote statistical significance at the $0.01,0.05$, and 0.10 level, respectively.

In addition, from the table 3 we can see that the firm size is positively related to the probability of excess credit, the larger of enterprises, the higher the probability of corporate excess credit. This is because large scale enterprises have strong credit ability, so their expected bankruptcy costs are low,and in our country, if an enterprise's scale is large, it is more easy to get government support and obtain excess credit ${ }^{[11]}$.

\subsection{Robustness Test}

One is to test the measure of excess credit. In this paper, we use the industry average benchmarking method for a robustness test. If a company's leverage ratio is higher than the industry's average, it is an excess credit company, industry classification we use the classification industry standards of CSRC (China Securities Regulatory Commission). Robust regression results show the conclusion is still established, there is no significant difference. So we can conclude the measure of excess credit is stable.

Another one is to examine whether excess credit and cash holdings are endogenous. There may be an endogenous problem between excess credit and cash holdings, since cash holdings can be considered a negative debt ${ }^{[12]}$. We use instrumental variables to verify the problem of endogenous. Drawing on the method of Mello 'D et al. ${ }^{[13]}$, the instrumental variables we use is the industry average excess credit / credit deficiency degree. Two independent equations were used to test the results. We verified that there was no endogenous problem between excess credit and cash holdings. Due to limited space, the robustness test results have not been listed in the article.

\section{Conclusion}

In this paper, we regarded the phenomenon of excess credit in current Chinese economy and society as a breakthrough point; studied the impact of cash holdings on the possibility of company's excess credit in Probit model. It was found that cash holdings is negatively related to excess credit, that is the possibility of corporate excess credit is higher when the level of corporate cash holdings is lower, it is consistent with the pecking order theory. In addition, we verified that there was no 
endogenous problem between excess credit and cash holdings, corporate cash holdings policy can affect the corporate financing decision.

This paper provides some reference for the research of excess credit. Excess credit is not only the product of corporate internal governance, but also an important consideration in corporate internal management. Chinese enterprises often find themselves with excess credit, moreover, Chinese enterprises have their own particularity, such as the nature of the enterprise, and therefore this article has certain Chinese characteristics and may not accurately describe the foreign situation. Whether the conclusions of the study are applicable to foreign enterprises remains to be studied.

\section{References}

[1] Baxter N.D., Cragg J.G. Corporate choice among long-term financing instruments. Review of Economics \& Statistics. 52 (1970) 225-235.

[2] Titman, Sheridan. The determinants of capital structure choice. Journal of Finance. 43(1988)1-19.

[3] Fama E.F., French K.R. Taxes, financing decisions, and firm value. Journal of Finance. 53 (1998) 819-843.

[4] Rajan R., Zingales L. What do we know about capital structure? Some evidence from international data. Journal of Finance. 50(1995) 1421-1460.

[5] Opler T., Pinkowitz L., Stulz R. et al. The determinants and implications of corporate cash holdings. Journal of Financial Economics. 52 (2008) 3-46.

[6] Bigelli M., Sánchez-Vidal J. Cash holdings in private firms. Journal of Banking \& Finance. 36 (2012) 26-35.

[7] Sunder L., Myers S. Testing static trade-off against pecking order models of capital structure. Journal of Financial Economics. 51 (1999) 219-244.

[8] Maosheng R., Wenzhou L., Jun H. Political relations, corporate excess loans and large shareholders' funds occupation - the evidence of Chinese family listed companies", Journal of Shanxi University of Finance and Economics. 35 (2013) 76-85.

[9] Wenzhou L., Maosheng R., Jun H. Ownship, political associations and corporate excess credit. Economic Review. 186 (2014) 77- 89.

[10] Loncan T. R., Caldeira J. F. Capital structure, cash holdings and firm value: a study of Brazilian listed firms. Social Science Research Network electronic journal. 25 (2014) 46-59.

[11] Zhengfei L., Yu X. An empirical study on the main factors affecting the capital structure of listed companies. Accounting research. 8 (1998) 34- 37.

[12] Terra M. C. T. Credit constraints in Brazilian firms: evidence from panel data. Revista Brasileira De Economia. 57 (2003) 443-464.

[13] D’Mello R., Krishnaswami S. , Larkin P.Determinants of corporate cash holdings: evidence from spin-offs. Journal of Banking \& Finance. 32(2008) 1209-1220. 